\title{
Glycated Albumin, An Early Biomarker of Several Pathologies
}

\author{
Pacciolla Rosana ${ }^{1}$, Marcello Leopoldo ${ }^{* 1,2}$, Colabufo Nicola Antonio* ${ }^{* 1,2}$, Colangiulo Santina ${ }^{1}$ and $^{2}$ \\ Leonetti $F^{2}$ \\ ${ }^{1}$ Biofordrug, spin-off University of Bari, Italy \\ ${ }^{2}$ Department of Pharmacy- Pharmaceutical Sciences, University of Bari A. Moro, Italy
}

*Corresponding author: Marcello Leopoldo, Department of Pharmacy- Pharmaceutical Sciences, University of

Bari A. Moro, Italy; Biofordrug, spin-off University of Bari, Italy

Nicola Antonio Colabufo, Department of Pharmacy- Pharmaceutical Sciences, University of Bari A. Moro, Italy; Biofordrug, spin-off

University of Bari, Italy

\section{ARTICLE INFO}

Received:

Published: 蔧 March 05, 2020

Citation: Pacciolla R, Marcello L, Colabufo Nicola A, Colangiulo S, Leonetti F. Glycated Albumin, An Early Biomarker of Several Pathologies. Biomed J Sci \& Tech Res 26(2)2020. BJSTR. MS.ID.004333.

\section{ABSTRACT}

The role of glycated albumin is determinant for early diagnosis in several pathologies. Obviously, it is with glycated hemoglobin elective for Diabetes diagnosis but the ratio albumin glycated and hemoglobin glycated could support the in vitro diagnosis in several pathologies of CNS such as Parkinson Alzheimer diseases and Epilepsy.

\section{Mini Review}

Human serum albumin, produced as preproalbumin is modified as mature albumin and secreted by the hepatocytes controlled by the gene localized on chromosome 4 [1,2]. It is present largely in human blood, about $50 \%$ of the others circulating protein displaying a concentration ranging from $30 \mathrm{~g} / \mathrm{L}$ to $50 \mathrm{~g} / \mathrm{L}$ in nonpathological subjects. On the contrary, its Molecular weight is 67 KDa resulting lower than other proteins [3].

Are present 585 aa constituting III domains each of them sub classified in two domains, A and B [2]. These domains give an alpha helix structure. Among Domains A and B are reported 17 bounds Cyst-Cyst whereas Cyst 34 is unbounded. This protein folding permits to react versus $\mathrm{pH}$ changes and other biophysical changes [4]. Useful oncotic pressure is due to electrical point (pI) of the protein giving a distributed negative charge [5,6]; moreover albumin binds reversibly metabolites, ions, fatty acid, bilirubin and drugs regulating the drug delivering [7-9]. Finally, albumin modulates the oxidative stress in plasma acting with free Cyst-34 $[10,11]$.

\section{Non-Enzymatic Glycated Albumin}

The high albumin serum concentration and the moderate half-life ( $\mathrm{t} 1 / 2=21$ days) with respect the other serum proteins is highly sensitive to direct glycation reaction. This is Maillard's reaction is glucose and free amine group of albumins giving a labile intermediate "Shiff base" that rearranges itself (Amadori mechanism) giving fructose-amine derivatives displaying moderate stability [12,13]. Both Shiff base and fructose-amine derivatives are the preliminary products of glycated albumin [14]; however, the last one could give heterocycles such as piranosyl- and furanosyladducts [15]. Other pathways could give, due to several oxidative or cleavage or re-modelling processes, stable compounds so called AGE (Advanced Glycation End product) [16]. 
Albumin with respect to Hemoglobin is more sensitive to Amadori reaction that Hemoglobin because the first reacts with free glucose whereas the last one is an intracellular protein. In addition, both albumin short half-life and the availability of albumin $\mathrm{N}$-lysine groups shows leads to consider low the reactivity of $\mathrm{N}$-valine present on $\beta$-chain of $\mathrm{Hb}$ with respect to $\mathrm{N}$-lysine groups. The glycation rate of albumine is 4.5 -fold higher than hemoglobin and the glycated hemoglobin/albumin ratio is $1: 2,9$ [17]. The most important nucleophilic addition groups of albumins are Lys, and Cyst and arginine although the most important fragment is Lys525 where about $30 \%$ of final product is obtained $[18,19]$. When Cys 34 is involved, albumin is strongly modified in particular is reduced antioxidative properties of protein depicting a pathologic phenotype of protein [20].

High glycated albumin concentration, due to AGE products, several organs such as coronary arteries, cardiovascular system kidney and CNS could give several diseases due to AGE-RAGE interaction. RAGE are specific AGE receptors localized on endothelial glial system, macrophages and muscle [21]. AGERAGE interaction stimulates the $\mathrm{kB}$ nuclear factor the modulates proinflammatory molecules IL-1, IL-6, IL-8 TNF-a and compounds involved in atherosclerotic events such as ICAM-1 and VCAM-1. The first most important aspect due to the activation of these pathways is the presence of ROS that leads to complications in particular at middle long term of Diabetes Mellitus. At kidney level, glycated albumin stimulates epithelial cells producing pro-oxidative molecules that are involved in several kidney disease $[22,23]$. At CNS level AGE compounds stimulates oxidative stress and consequently, the neuro-inflammatory processes. Several diseases seem to be related to the presence of AGE in CNS, such as Parkinson, Alzheimer, Huntington pathology [24,25]. In Alzheimer disease AGE are accumulated in pyramidal neuron where both lysosomes and endosomes could give macro complex with $\beta$-amyloid, MAPtau and APO-E4 molecules. Moreover, glycated albumin could overexpress APP inducing an accumulation of $\beta$-amyloid plaques. In Parkinson's disease AGE compounds links $\alpha$-synuclein producing macro-compounds with high cytotoxicity [26].

\section{Advantages of Glycated Albumin as Early Biomarker}

Glycated albumin although is a biomarker almost unknown, is middle term a glycaemic parameter because of its hal-life (T1/2 = 20 days) with respect to HbA1c. In fact, glycated albumin early gives the status of glycemic compensation and so is useful in monitoring fast changes of glycaemic parameter $[27,28]$. In addition, considering that the glycosylation reaction is easier with albumin than haemoglobin could be considered a specific biomarker in cardiovascular risk [29]. Moreover, as previously illustrated, promotes inflammatory steps endothelial dysfunction the renal fibrosis and atheroma plaques [29,30]. The most important parameters employed in evaluating diabetic patients are glycated haemoglobin and plasmatic glucose. The first is a longterm biomarker whereas the last one is for daily evaluation (24 h). However, the glycated haemoglobin values should be actually weighed in patients affected by haemolytic anaemia, in the presence of iron deficiency, and in subject in haemodialysis [31,32].

In fact, in haemolytic anaemia and other pathologies that cause erythrocytes mechanic disruption is possible find lower HbA1C values whereas this value could be higher in iron deficiency anemia or hemoglobin pathologies with respect standard reference. In these pathologies is better albumin glycated instead of corresponding hemoglobin although the first one is not very useful in hyperthyroidism nephrotic syndrome and in obesity because in these conditions an increased metabolism of albumin and therefore of glycated albumin has been observed [33-35]. Considering all these considerations, it would good clinical practice consider GA/ $\mathrm{HbA1C}$ ratio rather than each single value. In a recent study has been

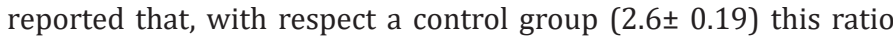
was highest in macrocytic anaemia $(3.4 \pm 0.50)$, normocytic anemia (2.8 \pm 0.31$)$, in dialysis patients $(3.3 \pm 0.52)$, in hypothyroidism (3.0 $\pm 0.38)$ chronic live disease $(3.0 \pm 0.39)$, live cirrhosis $(3.8 \pm 0.62)$ whereas this ratio was lowest in microcytic anaemia $(2.5 \pm 0.23)$, nephrotic syndrome $(1.6 \pm 0.28)$ and hyperthyroidism $(2.2 \pm 0.24)$ [36]. In conclusion, glycated album is useful not only to corroborate and screen diabetes mellitus but also to evaluate the risk in several pathologies. Recently it has been reported that subject with normal glucose tolerance displaying high GA / HbA1c ratio had a higher risk for Alzheimer disease with respect subject with low GA /HbA1c ratio. Similar trend was found in subject with glucose intolerance. Considering this report is possible suggest that $\mathrm{GA} / \mathrm{HbA} 1 \mathrm{c}$ ratio-but not $\mathrm{HbA1c}$ or GA alone might a useful biomarker for AD risk [37].

\section{References}

1. Hawkins JW, Dugaiczyk A (1982) The human serum albumin gene: structure of a unique locus. Gene 19(1): 55-58.

2. Peters TJ (1995) All about Albumin Biochemistry, Genetics, and Medical Applications. Academic Press, San Diego, pp. 432.

3. Evans TW (2002) Albumin as a drug biological effects of albumin unrelated to oncotic pressure, Aliment Pharmacol. Ther 16(Suppl 5): 6-11.

4. Foster JF (1977) Albumin Structure, Function and Uses. Pergamon, Oxford p. 53e84.

5. Scatchard G, Batchelder AC, Brown A (1944) Chemical, clinical, and immunological studies on the products of human plasma fractionation. Vi. The osmotic pressure of plasma and of serum albumin. J Clin Invest 23(4): 458-464

6. J Figge, TH Rossing, V Fencl (1991) The role of serum proteins in acidbase equilibria. J Lab Clin Med 117(6): 453-467.

7. Waldmann TA (1977) Albumin Structure, Function and Uses. Pergamon Press, New York, USA. pp. 255-273.

8. Wood M (1986) Plasma drug binding: implications for anesthesiologists. Anesth Analg 65(7): 786-804.

9. Kratz F (2008) Albumin as a drug carrier: design of prodrugs, drug conjugates and nanoparticles. J Control Release 132(3): 171-183. 
10. Bourdon E, Blache D (2001) The importance of proteins in defense against oxidation. Antioxid Redox Signal 3(2): 293-311.

11. Halliwell B (1988) Albumin e an important extracellular antioxidant? Biochem. Pharmacol 37(4): 569-571.

12. Hartog JW, Voors AA, Bakker SJ, Smit AJ, van Veldhuisen DJ (2007) Advanced glycation end-products (AGEs) and heart failure: Pathophysiology and clinical implications. Eur J Heart Fail 9(12): 11461155.

13. Ulrich P, Cerami A (2001) Protein glycation, diabetes, and aging. Recent Prog Horm Res 56: 1-21.

14. Thornalley PJ (1999) The clinical significance of glycation. Clin Lab 56: 263-273.

15. Cohen MP (2003) Intervention strategies to prevent pathogenetic effects of glycated albumin. Arch. Biochem. Biophys 419(1): 25-30.

16. Cohen MP, Shea E, Chen S, Shearman CW (2003) Glycated albumin increases oxidative stress, activates NF-kappa B and extracellular signalregulated kinase (ERK), and stimulates ERK-dependent transforming growth factorbeta1 production in macrophage RAW cells. J Lab Clin Med 141(4): 242-249.

17. Mo Y, Ma X, Li H, Ran X, Yang W, et al. (2016) Relationship between glycated albumin and glycated hemoglobin according to glucose tolerance status: A multicenter study. Diabetes Res Clin Pract 115: 1723.

18. Garlick RL, Mazer JS (1983) The principal site of nonenzymatic glycosylation of human serum albumin in vivo. J Biol Chem 258(10): 6142-6146.

19. Iberg N, Fluckiger R (1986) Nonenzymatic glycosylation of albumin in vivo. Identification of multiple glycosylated sites. J Biol Chem 261(29): 13542-13545.

20. Baraka Vidot J, Guerin Dubourg A, Bourdon E, Rondeau P (2012) Impaired drug-binding capacities of in vitro and in vivo glycated albumin. Biochimie 94(9): 1960-1967.

21. Vetter SW (2015) Glycated serum albumin and AGE receptors. Adv Clin Chem 72: 205-275.

22. Ziyadeh FN, Han DC, Cohen JA, Guo J, Cohen MP (1998) Glycated albumin stimulates fibronectin gene expression in glomerular mesangial cells: involvement of the transforming growth factor-beta system. Kidney Int 53: 631-638.

23. Chen S, Cohen MP, Ziyadeh FN (2000) Amadori-glycated albumin in diabetic nephropathy: pathophysiologic connections. Kidney Int. Suppl 77: S40-44.

24. Kaufmann E, Boehm BO, Süssmuth SD, Kientsch-Engel R, Sperfeld $\mathrm{A}$, et al. (2004) The advanced glycation end-product $\mathrm{N}$ epsilon(carboxymethyl) lysine level is elevated in cerebrospinal fluid of patients with amyotrophic lateral sclerosis. Neurosci. Lett 371: 226-229.
25. Anzilotti S, Giampà C, Laurenti D, Perrone L, Bernardi G, et al. (2012) Immunohistochemical localization of receptor for advanced glycation end (RAGE) products in the R6/2 mouse model of Huntington's disease. Brain Res. Bull 87: 350-358.

26. Li J, Liu D, Sun L, Lu Y, Zhang Z (2012) Advanced glycation end products and neurodegenerative diseases: Mechanisms and perspective J Neur Sci 317: $1-5$.

27. Lu JM, Ji LN, Li YF, Li QM, Lin SS, et al. (2016) Glycated albumin is superior to glycated hemoglobin for glycemic control assessment at an early stage of diabetes treatment: A multicenter, prospective study. J Diabetes Complications 30: 1609-1613.

28. Takahashi S, Uchino H, Shimizu T, Kanazawa A, Tamura Y, et al. (2007) Comparison of glycated albumin (GA) and glycated hemoglobin (HbA1c) in type 2 diabetic patients: usefulness of GA for evaluation of short-term changes in glycemic control. Endocr J 54: 139-144.

29. Tominaga M, Eguchi H, Manaka H, Igarashi K, Kato T, et al. (1999) Impaired glucose tolerance is a risk factor for cardiovascular disease, but not impaired fasting glucose. The Funagata Diabetes Study. Diabetes Care 22: 920-924.

30. Lim AI, Chan LYY, Tang SCW, Lai KN, Leung JCK (2014) Albumin and glycated albumin activate KIM-1 release in tubular epithelial cells through distinct kinetics and mechanisms. Inflamm Res 63: 831-839.

31. Inaba M, Okuno S, Kumeda Y, Yamada S, Imanishi Y, et al. (2007) Glycated albumin is a better gly-cemic indicator than glycated hemoglobin values in hemodialysis patients with diabetes: effect of anemia and erythropoietin injection. J Am Soc Nephrol 18: 896-903.

32. Fitzgibbons JF, Koler RD, Jones RT (1976) Red cell age-related changes of hemoglobins AIa+b and AIc in normal and diabetic subjects, J Clin Invest 58: 820-824.

33. Koga M, Murai J, Saito H, Matsumoto S, Kasayama S (2009) Effects of thyroid hormone on serum glycated albumin levels: study on nondiabetic subjects. Diabetes Res Clin Pract 84: 163-167.

34. Nishimura R, Kanda A, Sano H, Matsudaira T, Miyashita Y, et al. (2006) Glycated albumin is low in obese, non-diabetic children. Diabetes Res Clin Pract 71: 334-338.

35. Miyashita Y, Nishimura R, Morimoto A, Matsudaira T, Sano H, et al. (2007) Glycated albumin is low in obese, type 2 diabetic patients. Diabetes Res. Clin Pract 78: 51-55.

36. Miyamoto H, Tao X, Kohzuma T, Ohnishi A (2018) Influences of Anemia, Kidney Disease, Thyroid Dys-function, and Liver Disease on the Ratio of Glycated Albumin to Hemoglobin A1c J Diabetes Sci Tech 12(5): 10821083.

37. Mukai N, Ohara T, Hata J, Hirakawa Y, Yoshida D, et al. (2017) Alternative Measures of Hyperglycemia and Risk of Alzheimer's Disease in the Community: The Hisayama Study. J Clin Endocrinol Metab 102: 30023010
ISSN: 2574-1241

DOI: $10.26717 /$ BJSTR.2020.26.004333

Marcello Leopoldo. Biomed J Sci \& Tech Res

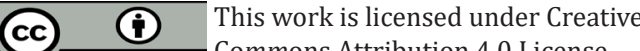

This work is licensed under Creat
Commons Attribution 4.0 License

Submission Link: https://biomedres.us/submit-manuscript.php

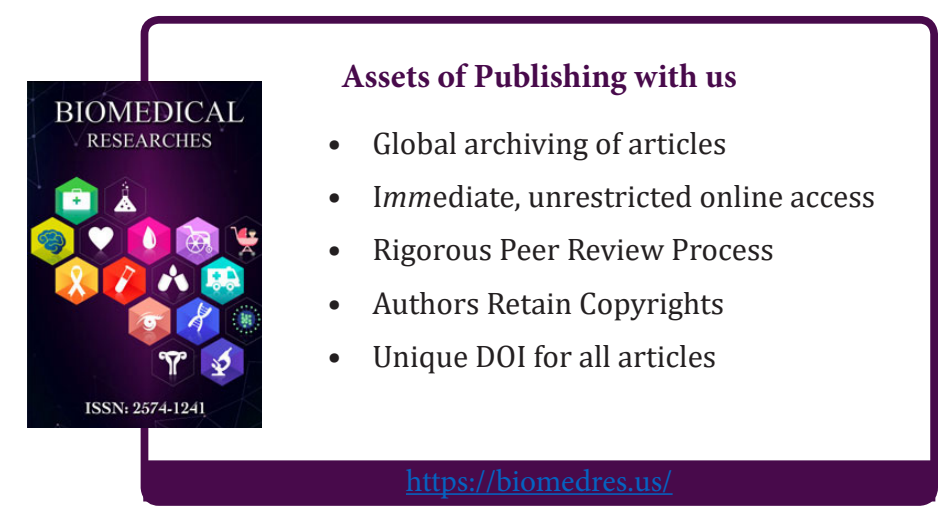

